\title{
YEARBOOK ON HUMAN RIGHTS FOR 1947
}

\section{A Unifed Nations Publication}

This second volume in the series projected by the Human Rights Division of the UN Secretariat is broader in scope than the 1946 volume, containing not only constifutional, legislative and international texts relating to human rights enacted in 1947, but also a full account of the UN's activities in this field since 1945.

$\$ 6.00$

\section{DOCUMENTARY BACKGROUND OF WORLD WAR II, 1931-1941}

\section{James W. Gantenbein}

"The editor has selected an amazingly comprehensive list of about 450 documents and speeches covering the incidents in every important country during the years 1931-1941. The book is indispensable to the student of this decade."-American Historical Review.

$\$ 10.00$

\section{YEARBOOK OF THE UNITED NATIONS, 1947-48}

\section{A United Nations Publication}

A detailed account of the work of the UN and its specialized agencies from July, 1947 to September, 1948. Full references to original documents and to questions covered in the first Yearbook. Charts, maps, documentary annexes, bibliography, UN Who's Who, and index.

$\$ 12.50$

\section{LIBRARY CLASSIFIED CATALOGUE}

A complete catalogue of the world-famous library of the International Institute of Agriculture at Rome, published by the Food and Agriculture Organization of the United Nations. Bilingual, English and French. Foreword, introduction, explanatory notes, catalogue of books, catalogue of bulletins, author and subject index.

2427 pages.

$\$ 30.00$

\section{International Documents Service COLUMBIA UNIVERSITY PRESS}

